\title{
Initial reading and writing skills in childhood education: achievement sample in the Northeast of Brazil for obtaining specific regional performance standards
}

\author{
Américo Nobre Gonçalves Ferreira Amorim ${ }^{1}$ \\ https://orcid.org/0000-0002-7834-2057 \\ Natália Martins Dias ${ }^{2}$ \\ https://orcid.org/0000-0003-1144-5657 \\ Emilia Xavier da Silva Albuquerque ${ }^{1}$ \\ https://orcid.org/0000-0002-9747-2295 \\ Vanessa Cristina da Silva ${ }^{1}$ \\ https://orcid.org/0000-0002-6360-5010 \\ Amanda Christina Gomes Pereira Falcão' \\ https://orcid.org/0000-0001-9846-7589 \\ Vera Gabrielly Rangel Guerra ${ }^{1}$ \\ https://orcid.org/0000-0002-1452-6914 \\ Maíra Hermínio da Silva ${ }^{1}$ \\ https://orcid.org/0000-0002-8569-1191 \\ Larissa Laís dos Santos ${ }^{1}$ \\ https://orcid.org/0000-0002-5738-5488
}

Escribo Inovação para o Aprendizado, Recife, Pernambuco, Brasil.

2 Universidade Federal de Santa Catarina UFSC, Florianópolis, SC, Brasil.

Research support source: This

research was conducted with financial support from the Conselho Nacional de Desenvolvimento Científico e Tecnológico (CNPq) through RHAE-Inovação and bolsas de produtividade em pesquisa $\mathrm{e}$ desenvolvimento tecnológico e extensão inovadora. The Project was also supported by the Fundação de Amparo à Ciência e Tecnologia de Pernambuco (FACEPE), through the Programa Pesquisador na Empresa de Pernambuco (PEPE). Lastly, it counted on financial and technical support from the Escribo Inovação para 0 Aprendizado.

Conflict of interests: Nonexistent

CC)
Received on: August 15, 2019
Accepted on: November 5, 2019
Corresponding address:
Américo Amorim
Estrada do Arraial, 2510 - SI 0007
CEP: 52051 -380 - Recife, Pernambuco,
Brasil
E-mail: americo@escribo.com

\section{ABSTRACT}

Purpose: the study aims to obtain preliminary normative data for early reading and writing skills of 5-year-old children in a sample from the Northeast of Brazil. It also aims to investigate the effects of the type of school (public vs. private) and the time of assessment (beginning vs. end of the school year), and whether there were significant differences in performance, as compared to those of children from the Southeast of Brazil.

Methods: 389 5-year-old children from 17 private and 12 public schools were assessed in the beginning and at the end of the school year, by using the Reading and Writing Test. Each student was individually assessed in the two times of the year. Appropriate statistical tests were applied, adopting a significance level lower than 0.05 .

Results: the progress in the performance of private school children was stronger than that of their peers from public schools, accentuating the existing learning gap. The comparison with normative data from the Southeast revealed that the public schools in the Northeast outperformed those in all topics of comparison. Private schools in the Southeast had a better performance at the beginning of the year, but were outperformed by those of the Northeast at the end of the year.

Conclusion: the differences in performance identified in the samples suggest the need for specific norms by geographical regions of Brazil, and by type of school (public or private). The data presented in this study are preliminary and can be enlarged in future studies.

Keywords: Reading; Handwriting; Education; Child Rearing 


\section{INTRODUCTION}

The evolution of research indicated that stimulating specific skills before students enter elementary school is beneficial for their learning of reading and writing". In preschool and kindergarten (children aged four and five years old), the children expand their vocabulary ${ }^{2}$, develop phonological awareness skills ${ }^{3}$, and begin reading and writing their first words 4 .

In this perspective, which sees learning how to read and write as a process beginning in early childhood, the Base Nacional Comum Curricular - BNCC $^{5}$ (Brazilian common core) has established learning and development goals related to reading and writing. Among the goals that must be achieved by children in the age range of four and five-years-old, the following stand out:

- "(EI03EF01) Expressing ideas, desires,and feelings about their experiences, through oral and written language (spontaneous writing);

- (EI03EF03) Choosing books and leafing through them, being guided by themes and illustrations, and trying to identify familiar words;

- (EIO3EF06) Producing their own oral and written stories (spontaneous writing), in situations with significant social function;

- (EI03EF07) Raising hypothesis about text genres published in well-known media, resorting to graphic and/or reading observation strategies;

- (El03EF09) Raising hypothesis regarding written language, registering words and texts, through spontaneous writing" (p. 49).

As established by the legal framework that instituted the BNCC, all Brazilian public and private schools must conform to these requirements by 2020 . The curriculum of the institutions will need to be redesigned, as well as the processes and instruments used by them to evaluate whether their students are achieving the goals established in the requirements of the BNCC.

In this new context, it is essential that the schools have evaluative processes and instruments capable of lending support to pedagogical decision-making along with their internal (teachers, assistants, coordinators, principal) and external stakeholders (families, department of education, media). This demand can be met with the use of standardized evaluation instruments to assess the students' performance and compare them to a standard reference. An option that is being investigated to meet such demand in kindergarten is the use of the Reading and Writing Test (RWT).

The RWT instrument aims to assess initial reading and writing skills, specifically the reading and writing of isolated words and pseudowords with simple syllabic structure (C-V, mono- and disyllable) $)^{6}$. The psychometric properties of the RWT have been evaluated in previous studies conducted in the Southeast Region of Brazil ${ }^{4,6,7}$, with promising results.

The importance of measuring the ability to read and write words in kindergarten is related to the predictive power of these abilities concerning theirliteracy performance ${ }^{8,9}$ in the following grades. For example, a recent study identified that precursory skills in kindergarten, among them, the reading of pseudowords, are significantly related to reading comprehension in high school ( $10^{\text {th }}$ grade, according to the study). The finding suggests long-term stability in the development of reading skills ${ }^{10}$. Further on the initial writing skills, there is evidence of its predictive power regarding the posterior development of literacy skills. One example of these precursory skills is the writing of one's own name ${ }^{11}$.

However, the wide use of a scanning instrument of the initial reading and writing skills in education depends on the existence of norms that would offer assurance to administrators and educators regarding their students' performance, so that they may take such indicators into account in their school administration process. Such assurance may be obtained if the measuring instrument offers norms that take into consideration the cultural aspects of the region where the students live, and the socioeconomic level of their families. The existence of norms adequate for the region and socioeconomic level is also essential for the results of educational research in different regions to be compatible. The RWT has preliminary norms that were published for public and private school children from the Southeast Region of Brazil7; nevertheless, it lacks new studies to consolidate these results and evaluate its applicability in other regions of the country.

The availability of measurement instruments as the RWT and of normative standardsthat allow professionals to interpret the scores obtained by their students may enable the child's development to be monitored even in an early age ${ }^{12}$. Such monitoring makes it possible for the students' development to be followed up from kindergarten, as well as possible indicators of difficulties in learning to be identified before the national standardized tests conducted by the INEP/MEC. The availability of standardized instruments for the assessment of the initial reading and writing skills in kindergarten is also important to make research easier to be conducted as they aim at 
evaluating the effectiveness of educational interventions and programs. In this regard, the early identification of children at risk of having reading difficulties may be a starting point for implementing response to intervention (RTI) programs ${ }^{13}$.

This study aimed to provide preliminary performance benchmarks for the initial reading and writing skills of our sample. These benchmarks could be used as a reference for the professionals working in this region and, eventually, indicate whether there is the need for further studies in other places of the Northeast Region, in the sense of developing sturdy and specific norms for this region. Also, this study aimed at investigating the effect of the type of school (public vs. private) and the time of assessment (beginning vs. end of the school year) on the performance of the northeastern sample, so as to justify the availability of specific performance standards. Furthermore, it sought to investigate whether there are differences in the performance of early reading and writing skills of northeastern children in relation to the preliminary norms already provided in the RWT, in sample with data from the Southeast Region, as made available by León et al. ${ }^{7}$.

\section{METHODS}

\section{Participants}

This project was approved by the Research Ethics Committee of the Centro Universitário Fundação Instituto de Ensino para Osasco FIEO (evaluation report number 967.5590). The total sample comprised 389 five-year-old kindergarten children in the metropolitan area of a capital city in the Northeast region of Brazil. These children were students of 17 private schools situated in five cities of the studied metropolitan area, and 12 public schools located in the city which had the metropolitan area's best score in the Índice de Desenvolvimento da Educação Básica (IDEB) (Elementary Education Development Index). The public school sample counted with 149 children (38.3\%), whereas the private one had 240 (61.7\%). In this sample, all the children known to have disabilities were excluded, based on the information obtained from the schools' coordinators and teachers.

The subgroup of private school students was characterized for belonging to families of high educational attainment, $94 \%$ of the parents having a higher education diploma, whereas in Brazil as a whole only $15 \%$ of the citizens have finished an undergraduate program ${ }^{14}$. According to data from Prova Brasi/ ${ }^{15}$, in the public schools of the municipality where the schools of this sample are situated, only $9 \%$ of the parents had completed a higher education program. All the 389 children participated in both assessments, at the beginning (March) and at the end (December) of the school year.

\section{Instrument}

The Reading and Writing Test (RWT) was developed to assess early reading and writing skills in preschool and kindergarten ${ }^{4}$. The first part of this assessment, the reading subtest, consists of eight words and two pseudowords, which must be read aloud by the student. In the second part, the writing subtest, the researcher dictates eight words and two nonwords for the student to write. Each word is more complicated than the previous ones. The words are classified according to their regularity and frequency of use. The score on the test is calculated by the percentage of letters correctly read or written by the student so that the performance ranges from zero to $100 \%$ for reading and writing ${ }^{4}$.

The RWT has been previously used and has presented adequate psychometric properties ${ }^{7}$. In the study by Pazeto et al. ${ }^{4}$, with a sample of 94 kindergarten students, sturdy and significant correlations were observed between the performance on the RWT and scores in phonological awareness $(0.76$ and 0.80 , $p<0.01$ ), knowledge of sounds ( 0.73 and $.87, p<0.01$ ), and knowledge of letters (.49 and 0.57, $p<0.01$ ). The instrument is to be applied individually, with an approximate duration of 10 minutes, and it is available in Pazeto et al. ${ }^{6}$.

\section{Procedure}

The team that applied the instrument was trained before the beginning of the data collection. In compliance with the protocol, we obtained approval from the Research Ethics Committee, and the signing of the Informed Consent Form by the adults responsible for the participating children, besides the verbal consent given by each child before the application of the RWT was begun. The students were individually assessed in a room made available by the school. The assessments lasted 10 minutes per student, on average.

The application of the reading subtest was recorded in audio so that it would be possible to establish the level of agreement between multiple evaluators after 
the application of the instrument had been concluded. A second rater, who did not have access to the scores attributed by the one who applied the instrument, reassessed the answers given by the students using the audio recorded during the application and the response card with the words written by the students.

Fifteen percent of all the participating students were selected to have their scores rated by the second evaluator. Using the one-way random effect model of the SPSS 25, it was possible to calculate the ICC for each one of the RWT subtests. For the reading subtest, the ICC was 0.98 at the beginning of the school year and 0.99 at the end of the year. For the writing subtest, the ICC was 0.99 at the beginning of the year, and 0.99 at the end. These ICCs indicate that the scores obtained are reliable and that there was no bias on the part of the evaluator ${ }^{16}$.

\section{Data Analysis}

For the comparison between the types of school (public vs. private), and time of the assessment (intrasubjects variable: March vs. December), repeated measure variance analysis was conducted. The comparison with data from the normative sample was performed using the Wilcoxon test. The standard score was calculated based on the formula: (( (Raw score - Mean)/SD)*15) +100.

\section{RESULTS}

Table 1 presents descriptive statistics of the sample's performance in the reading and writing subtests of the RWT, in each time of the year, by type of school. It also presents the ANOVA repeated measures statistic for the type of school/time interaction effect.

Table 1. Performance on the reading and writing tests by the time of assessment and type of school

\begin{tabular}{|c|c|c|c|c|c|c|}
\hline \multirow[t]{2}{*}{ Test } & \multirow[t]{2}{*}{ Time } & \multirow[t]{2}{*}{ Type of School } & \multirow[t]{2}{*}{ Average } & \multirow{2}{*}{$\begin{array}{l}\text { Standard } \\
\text { Deviation }\end{array}$} & \multicolumn{2}{|c|}{$\begin{array}{c}\text { Repeated measures - Interaction } \\
\text { type of school/time }\end{array}$} \\
\hline & & & & & $F$ test & p-value \\
\hline \multirow{6}{*}{ Reading } & & Public & 4.93 & 11.41 & \multirow{6}{*}{174.85} & \multirow{6}{*}{$<0.001$} \\
\hline & March & Private & 23.07 & 29.81 & & \\
\hline & & Total & 16.34 & 26.14 & & \\
\hline & \multirow{3}{*}{ December } & Public & 13.16 & 24.81 & & \\
\hline & & Private & 73.22 & 32.32 & & \\
\hline & & Total & 50.84 & 41.57 & & \\
\hline \multirow{6}{*}{ Writing } & & Public & 9.01 & 12.48 & \multirow{6}{*}{114.11} & \multirow{6}{*}{$<0.001$} \\
\hline & March & Private & 30.35 & 28.68 & & \\
\hline & & Total & 22.40 & 26.03 & & \\
\hline & \multirow{3}{*}{ December } & Public & 21.13 & 21.53 & & \\
\hline & & Private & 71.27 & 28.24 & & \\
\hline & & Total & 52.58 & 35.51 & & \\
\hline
\end{tabular}

F test - Fisher's test

In addition to the time/type of school interaction effect, presented in Table 1, there was a main effect regarding the time of assessment, with a general tendency of improvement from time 1 to time 2 (reading: $\mathrm{F}=339.74$, and $p \leq 0.001$; writing: $\mathrm{F}=387.07$ and $p \leq$ 0.001 ); and, the type of school, with superior performance by the private schools (reading: $F=260.08$, and $p \leq 0.001$; writing: $F=246.26$ and $p \leq 0.001$ ). The time/type of school interaction effect may be seen more clearly in Figure 1, both in the reading and the writing measures. For both types of school, there was an improvement in performance in terms of the growing percentage of correct answers from time 1 to time 2 . Nonetheless, it can be seen that the growth curve of the children from private schools is much steeper and that the distance between the children of public and private schools tends to increase. 


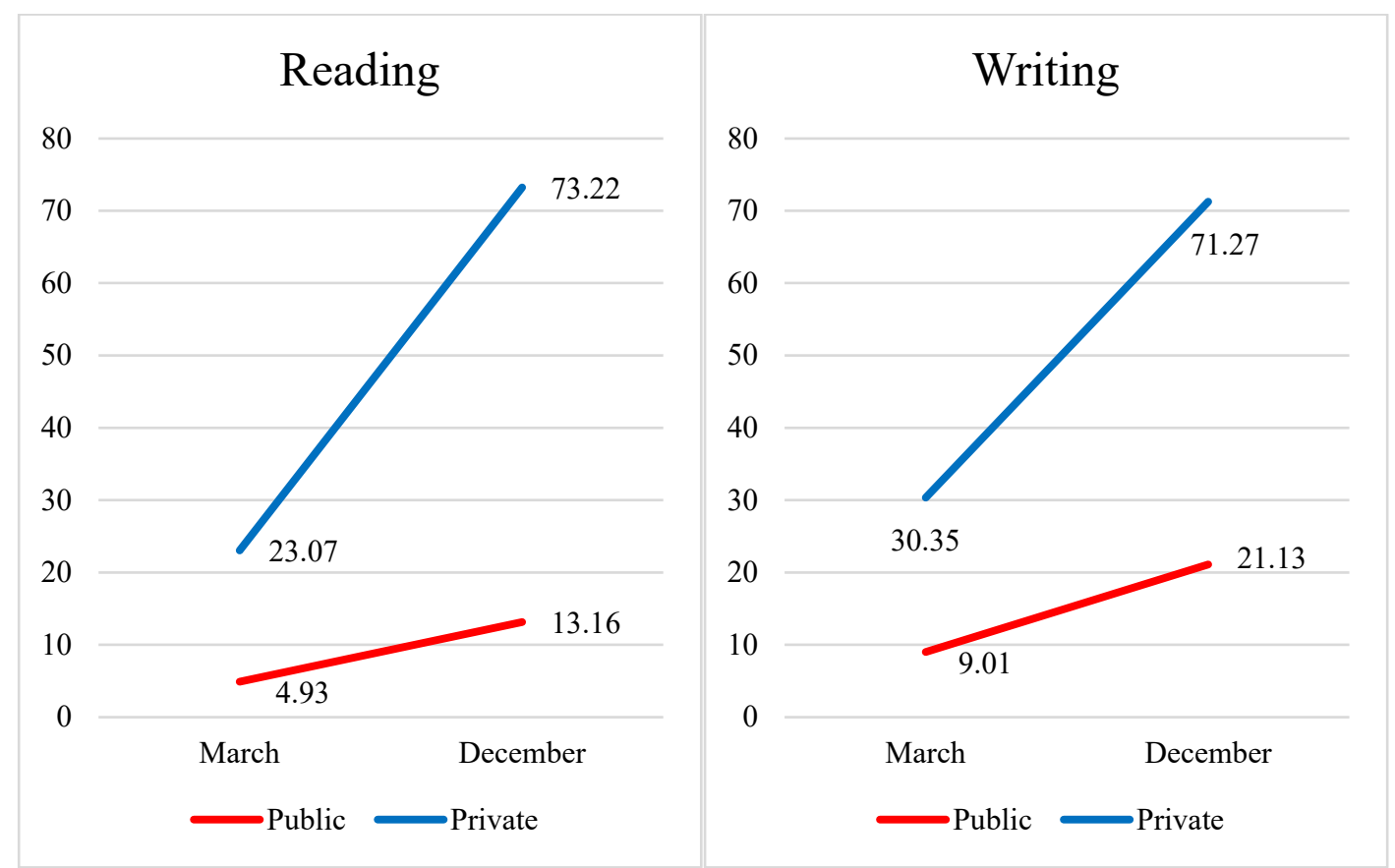

Figure 1. Performance in the reading and writing test by type of school, in the two times of assessment

Table 2 includes the mean and SD of the same age sample (five years old), the expected score based on the existing preliminary norms, and the median calculated from the sample in León et al. ${ }^{7}$. The median is the index to be considered in the Wilcoxon analysis for the comparison of the present data with those of the normative sample.

Table 2. Comparison between performances of the sample of this study and the data published in León et al. ${ }^{7}$

\begin{tabular}{|c|c|c|c|c|c|c|c|c|}
\hline \multirow{2}{*}{\multicolumn{2}{|c|}{ Types of school }} & \multirow[b]{2}{*}{$\begin{array}{c}\text { Time of } \\
\text { assessment }\end{array}$} & \multicolumn{3}{|c|}{ Sample of this study } & \multicolumn{3}{|c|}{ Sample from the Southeast* } \\
\hline & & & $\begin{array}{l}\% \text { of right } \\
\text { answers } \\
\text { (Average) }\end{array}$ & $\begin{array}{l}\text { Standard } \\
\text { deviation }\end{array}$ & Median & $\begin{array}{l}\% \text { of right } \\
\text { answers A } \\
\text { (SD) }\end{array}$ & Median & $\begin{array}{l}\text { Expected } \\
\text { score (\%) }\end{array}$ \\
\hline \multirow{4}{*}{ Public } & \multirow{2}{*}{ Reading } & March & 4.93 & 11.41 & 0 & \multirow{2}{*}{$2.5(11.68)$} & \multirow{2}{*}{0} & \multirow{2}{*}{3} \\
\hline & & December & 13.16 & 24.81 & 1.67 & & & \\
\hline & \multirow{2}{*}{ Writing } & March & 9.01 & 12.48 & 5 & \multirow{2}{*}{$5.9(13.66)$} & \multirow{2}{*}{0} & \multirow{2}{*}{6} \\
\hline & & December & 21.13 & 21.53 & 13.3 & & & \\
\hline \multirow{4}{*}{ Private } & \multirow{2}{*}{ Reading } & March & 23.07 & 29.81 & 11.25 & \multirow{2}{*}{$56.7(38.10)$} & \multirow{2}{*}{73.05} & \multirow{2}{*}{$55-60$} \\
\hline & & December & 73.22 & 32.32 & 86.67 & & & \\
\hline & \multirow{2}{*}{ Writing } & March & 30.35 & 28.68 & 21.25 & \multirow{2}{*}{$54.9(38.55)$} & \multirow{2}{*}{54.4} & \multirow{2}{*}{55} \\
\hline & & December & 71.27 & 28.24 & 84.58 & & & \\
\hline
\end{tabular}

* Based on the results available in León et al.7, whose collection took place during the first semester of the years when the data were collected. SD - standard deviation.

The comparison between the performance of the children of this study with those of the normative sample inLeón et al. ${ }^{7}$, with children from the Southeast Region, revealed significant differences, presented in Table 3. The sample in this study obtained better results in all comparisons for public schools. For private schools, the Southeast schools displayed better performance at time 1; however, the sample from the Northeast outperformed the Southeast schools at time 2 . 
Table 3. Analysis of differences between samples of this study and normative data

\begin{tabular}{cccc}
\hline Type of school & Test & Time of assessment & $\mathbf{z}$ \\
\hline \multirow{3}{*}{ Public } & Reading & March & $6.68^{\star}$ \\
& & December & $7.42^{\star}$ \\
& \multirow{2}{*}{ Writing } & March & $9.06^{*}$ \\
& \multirow{2}{*}{ Reading } & December & $10.00^{\star}$ \\
\hline \multirow{2}{*}{ Private } & & March & $-12.84^{*}$ \\
& \multirow{2}{*}{ Writing } & December & $2.11^{\star *}$ \\
& & March & $-9.95^{\star}$ \\
& & December & $7.38^{*}$ \\
\hline
\end{tabular}

${ }^{*} p<0,001{ }^{* *} p=0,035 z-$ Wilcoxon

The differences identified may be due to the time when the assessments were conducted. Even so, given the differences observed, the finding suggests the need for specific norms to be used with children from the Northeast. Furthermore, considering the differences between the types of school and between the time of assessment, developing referential data that take this variability into consideration can contribute to a more precise assessment. Tables 4 and 5 offer the standard score for northeastern children in the last year of kindergarten, from public and private schools, in two times of the school year. For the interpretation of the standard score, consider the reference of Figure 2.

\begin{tabular}{|c|c|}
\hline Standard score below 70 & very low \\
\hline Standard score between 70 and 84 & low \\
\hline Standard score between 85 and 114 & average \\
\hline Standard score between 115 and 129 & high \\
\hline Standard score equal or superior to 130 & very high \\
\hline
\end{tabular}

Figure 2. Interpretation of the standard score

Table 4. Preliminary normative data of the reading and writing test for public and private schools from the Northeast at the beginning of the school year (March)

\begin{tabular}{cccccc}
\hline Percentage of right & \multicolumn{2}{c}{ Standard score (5 years old) } & Percentage of right & \multicolumn{2}{c}{ Standard score (5 years old) } \\
\cline { 2 - 3 } answers in Reading & Public school & Private school & answers in writing & Public school & Private school \\
\hline 0 & 94 & 88 & 0 & 89 & 84 \\
1 & 95 & 89 & 1 & 90 & 85 \\
2 & 96 & 89 & 2 & 92 & 85 \\
3 & 98 & 90 & 3 & 93 & 86 \\
4 & 99 & 90 & 4 & 94 & 86 \\
5 & 100 & 91 & 5 & 95 & 87 \\
6 & 102 & 91 & 6 & 96 & 87 \\
7 & 103 & 92 & 7 & 98 & 88 \\
8 & 104 & 92 & 8 & 99 & 88 \\
9 & 106 & 93 & 9 & 100 & 89 \\
10 & 107 & 93 & 10 & 101 & 89 \\
15 & 114 & 96 & 15 & 107 & 92 \\
20 & 120 & 98 & 20 & 113 & 95 \\
25 & 127 & 101 & 25 & 119 & 97 \\
30 & 134 & 103 & 30 & 125 & 100 \\
\hline
\end{tabular}




\begin{tabular}{cccccc}
\hline Percentage of right & \multicolumn{2}{c}{ Standard score (5 years old) } & Percentage of right & \multicolumn{2}{c}{ Standard score (5 years old) } \\
\cline { 2 - 3 } answers in Reading & Public school & Private school & answers in writing & Public school & Private school \\
\hline 35 & 141 & 106 & 35 & 131 & 102 \\
40 & 147 & 108 & 40 & 137 & 105 \\
45 & 154 & 111 & 45 & 143 & 108 \\
50 & 161 & 114 & 50 & 149 & 110 \\
55 & 167 & 116 & 55 & 155 & 113 \\
60 & 174 & 119 & 60 & 161 & 116 \\
65 & 181 & 121 & 65 & 167 & 118 \\
70 & 187 & 124 & 70 & 173 & 121 \\
75 & 194 & 126 & 75 & 179 & 123 \\
80 & 201 & 129 & 80 & 185 & 126 \\
85 & 208 & 131 & 85 & 191 & 129 \\
90 & 214 & 134 & 90 & 197 & 131 \\
95 & 221 & 136 & 95 & 203 & 134 \\
100 & 228 & 139 & 100 & 209 & 136 \\
\hline
\end{tabular}

Table 5. Preliminary normative data of the reading and writing test for public and private schools from the Northeast at the end of the school year (December)

\begin{tabular}{cccccc}
\hline Percentage of right & \multicolumn{2}{c}{ Standard score (5 years old) } & Percentage of right & \multicolumn{2}{c}{ Standard score (5 years old) } \\
\cline { 2 - 3 } answers in Reading & Public school & Private school & answers in writing & Public school & Private school \\
\hline 0 & 92 & 66 & 0 & 85 & 62 \\
1 & 93 & 67 & 1 & 86 & 63 \\
2 & 93 & 67 & 2 & 87 & 63 \\
3 & 94 & 68 & 3 & 87 & 64 \\
4 & 95 & 68 & 4 & 88 & 64 \\
5 & 95 & 69 & 5 & 89 & 65 \\
6 & 96 & 69 & 6 & 90 & 65 \\
7 & 97 & 70 & 7 & 90 & 66 \\
8 & 97 & 70 & 8 & 91 & 66 \\
9 & 98 & 70 & 9 & 92 & 67 \\
10 & 98 & 71 & 10 & 92 & 68 \\
15 & 101 & 73 & 15 & 96 & 70 \\
20 & 105 & 76 & 20 & 100 & 73 \\
25 & 108 & 78 & 25 & 103 & 75 \\
30 & 111 & 80 & 30 & 107 & 78 \\
35 & 114 & 82 & 35 & 110 & 81 \\
40 & 117 & 85 & 40 & 114 & 83 \\
45 & 120 & 87 & 45 & 117 & 86 \\
50 & 123 & 89 & 50 & 121 & 89 \\
55 & 126 & 92 & 55 & 124 & 91 \\
60 & 129 & 94 & 60 & 128 & 94 \\
65 & 132 & 96 & 65 & 131 & 97 \\
70 & 135 & 99 & 70 & 135 & 99 \\
75 & 138 & 101 & 75 & 138 & 102 \\
80 & 142 & 103 & 80 & 142 & 105 \\
85 & 145 & 106 & 95 & 145 & 107 \\
90 & 148 & 110 & 95 & 149 & 110 \\
95 & 151 & 112 & 100 & 156 & 115 \\
100 & 154 & & & & \\
\hline
\end{tabular}




\section{DISCUSSION}

The early identification of children at risk of presenting reading and writing difficulties is a fundamental step for implementing programs to stimulate early literacy and prevent reading failure ${ }^{11-13}$. For such, early reading and writing skills, which have predictive power regarding later literacy skills, may be assessed at the beginning of formal education or immediately before it. The last year of kindergarten figures as a favorable moment for this type of screening. Nevertheless, standardized measures for such moments are scarce in the Brazilian national context.

Alongside with phonological awareness skills, which are considered essential predictors of laterliteracy skills ${ }^{17}$,early reading and writing have also been pointed as relevant precursors of more complex skills involving the use and mastery of the written language ${ }^{8-11}$. One of the advantages of early reading and writing assessments is their easiness of usage. Since they do not require special skills, they can be employed for clinical assessment and screening in schools. Such characteristic contrasts with the phonological awareness tests, which require appropriate knowledge and experience from the person applying them.

In agreement with that, the aim of this study was mainly to provide preliminary performance standards of early reading and writing skills for five-year-old children from a metropolitan area in the Northeast Region of Brazil. Such a goal was achieved, and the availability of these performance standards can contribute, from now on, to the usage of the RWT for screening northeastern children. It should be noted that the RWT offered only preliminary norms published only for children of the Southeast Region ${ }^{6,7}$.

Among its specific aims, the study investigated the effect of the type of school (public vs. private), and the time of assessment (beginning vs. end of the school year) on the performance of the northeastern sample. There was an interaction effect, as well as time and type of school effects. The time effect was expected as it denotes the gainsstemming from the schooling process. The type of school effect had already been well documented in the literature, especially with children already in school age ${ }^{18}$. Our data show that this difference is already evident in the course of kindergarten, as it had been previously identified in a pioneer study that found significant differences in the phonological awareness skills between children from public and private schools ${ }^{19}$. This finding further expands such findings to early reading and writing skills.
Another highlight here, associated with the interaction effect observed in the analysis, is related to the developmental curves of early reading and writing skills in the two times of assessment of the children from the public and private schools. That is, the children from private schools not only began kindergarten with stronger early reading and writing skills, but they also presented stronger progress throughout the school year. It is interesting to observe that, even in the December assessment, the children from the public schools did not equal the performance that the private school students displayed at the beginning of the year, in March, and that the performance gap between them tends to grow wider. Such an issue may both be associated with the quality of the stimulation received in the schools and reflects the quality and diversity of the stimulation that children may receive in their family environment. For instance, the variety of experiences that the children receive before they enter kindergarten may lead them to different levels of early literacy skills ${ }^{12}$.

Furthermore, in Brazil, the type of school is very much associated with the availability of educational resources and the socioeconomic level of the family. For example, $86 \%$ of private schools have broadband internet access, whereas only $54 \%$ of public schools have such resource ${ }^{20}$. Although the literature lacks this type of evidence for kindergarten,as an example, in higher schooling levels, the ENEM (Portuguese acronym for National High School Exam) microdata shows that the school's working condition and the families' socioeconomic characteristics explain $86 \%$ of the students' grades ${ }^{21}$. Having studied at a public school in elementary or high school is among the four variables most associated with low scores on the ENEM. On the other hand, the level of family income is the variable which most contributes to predicting the performance of the student on the ENEM, emphasizing that learning inequality in Brazil is related not only to the type of school the student attends but also to the family's socioeconomic level ${ }^{21}$. Moreover, the socioeconomic level has already been associated with cognitive development in childhood $^{22}$. Thus, the data obtained suggest the need for specific performance standards for time and type of school.

Another aim of the study was to investigate the performance differences in early reading and writing skills in northeastern children concerning the preliminary norms available on the RWT with a sample from the Southeast Region. It is interesting to note that, while the children from private schools in the Southeast 
had an advantage over their northeastern peers, the opposite occurred regarding public schools. This result was unexpected, considering that the municipality in the Northeast obtained grade 5.2 in the Índice de Desenvolvimento da Educação Básica (IDEB) of 2017, whereasthe schools from the study by León et al. ${ }^{7}$ were situated in a capital city in the Southeast (grade 6.0 in the IDEB), and a municipality of the metropolitan area (grade 5.8 in the IDEB).

The fact that the municipality in the Northeast presented a lowelDEB than that of the Southeast, and even whiledisplaying better performance in the initial reading and writing skills in kindergarten may be associated with the fact that, in the Northeast, it is common for such skills to be developed earlier than in the Southeast, as it is common to teach how to read and write before the first grade. A case that agrees with this information is that of Sobral, a municipality in the state of Ceará, which has been standing out in the continuing evolution of its educational indexes. In Sobral, the students undergo a process of systematic teaching of the early reading and writing skills, since kindergarten ${ }^{23}$. If this is the case, introducing activities that stimulate the development of these skills since kindergarten maybe an interesting instructional strategy for municipalities from the Southeast to strengthen their students' performance, in line with what has already been identified in the literature ${ }^{10}$.

Concerning private schools, the one that composed the sample in the normative study of the Southeast had phonic activities integrated into their kindergarten teaching curriculum. Of the 17 schools from the Northeast, only two developed phonics activities. The prevalence of institutions not developing phonics activities in the Northeast may explain the reduced performance of this sample when compared to that of the Southeast. Nevertheless, the empirical data shows the inadequacy of the existing RWT normative data $^{7}$ for the schools from the Northeast. The availability of local performance standards, above all, consider cultural and regional aspects (local curriculum, instructional strategies) and the student's socioeconomic characteristics (public vs. private).

Like every study, this one has limitations and, among them, the fact that data collection happened only in one metropolitan area of the Northeast. Also, the lack of a more specific assessment to investigate the variables that justify the exclusion of participants (e.g., an intelligence assessment). Future studies must be attentive to these limitations when replicating this study in other capitals and countryside towns of the Northeast and other regions of Brazil.

The relevance of instruments such as the RWT and performance standards for its interpretation, such as provided here, is in enabling the screening and early identification, with important implications for planning interventions and the children's development. It is the fact that children are exposed to different experiences before their entering formal education, and screening instruments can collaborate in identifying their strengths and weaknesses, aiding teachers in furnishing differential instruction to those who need greater support in this initial stage ${ }^{12}$. For Wood ${ }^{24}$, addressing the difficulties in reading early, aiming at minimizing the performance gap between children, would provide them with a better chance of development and of achieving their full learning potential and academic success.

\section{CONCLUSIONS}

The study made it possible for preliminary performance standards specific for the northeastern children to be provided in an already available test of early reading and writing skills. Such aim: 1 ) is in agreement with the national and international literature, which already mentions these skills as precursors of performance during the process of learning how to read and write, and after it; 2) conforms to current premises and goals of the $\mathrm{BNCC}^{5}$; and, 3) fits in the scope of health professionals working in schools to strengthen the teaching and learning processes, and the public education policies.

\section{ACKNOWLEDGEMENT}

To the financial support of the Conselho Nacional de Desenvolvimento Científico e Tecnológico (CNPq), through the RHAE-Inovação and Bolsas de Produtividade em Pesquisa e Desenvolvimento Tecnológico e Extensão Inovadora. To the Fundação de Amparo à Ciência e Tecnologia de Pernambuco (FACEPE), through the Programa Pesquisador na Empresa de Pernambuco (PEPE), andfor the financial and technical support of Escribo Inovação para o Aprendizado. 


\section{REFERENCES}

1. Chambers B, Cheung AC, Slavin RE. Literacy and language outcomes of comprehensive and developmental-constructivist approaches to early childhood education: a systematic review. Rev Educ Res. 2016;18(1):88-111. doi:10.1016/j. edurev.2016.03.003

2. Marulis LM, Neuman SB. The effects of vocabulary intervention on young children's word learning: a meta-analysis. Rev Educ Res. 2010;80(3):300-35. doi: $10.3102 / 0034654310377087$

3. Suortti O, Lipponen L. Phonological awareness and emerging reading skills of two- to five-year-old children. Early Child Dev Care. 2016;186(11):1703-21. doi:10.1080/03004430.2015 .1126832

4. Pazeto TCB, Seabra AG, Dias NM. Executive functions, oral language and writing in preschool children: development and correlations. Paidéia. 2014;24(58):213-22. doi:10.1590/1982-43272458201409

5. Ministério da Educação. Base nacional comum curricular. Brasília: Ministério da Educação. [cited 2018 aug 07). Available from http:// basenacionalcomum.mec.gov.br

6. Pazeto TCB, Leon CBR, Seabra AG. Avaliação de habilidades preliminares de leitura e escrita no início da alfabetização. Rev Psicoped. 2017;34(104):137-47.

7. León CBR, Almeida Á, Lira S, Zauza G, Pazeto TCB, Seabra AG et al. Phonological awareness and early reading and writing abilities in early childhood education: preliminary normative data. Rev. CEFAC. 2019;21(2):e7418. Doi:10.1590/1982-0216/20192127418

8. Barrera SD, Santos MJ. Conhecimento do nome das letras e habilidades iniciais em escrita. Bol Acad Pau Psico. 2016;36(90):1-15.

9. Pazeto TCB, Dias NM, Gomes CMA, Seabra AG. Prediction of reading and writing in Elementary Education through early childhood education. Psicol., Ciênc. Prof. 2019; (no prelo).

10. Stanley CT, Petscher $Y$, Catts H. A longitudinal investigation of direct and indirect links between reading skills in kindergarten and reading comprehension in tenth grade. Read Writ. 2018;31(1):133-53. doi:10.1007/s11145-017-9777-6

11. Campbell K, Chen YJ, Shenoy S, Cunningham AE. Preschool children's early writing: repeated measures reveal growing but variable trajectories.
Read. Writ, 2019;32(4): 939-61. doi:10.1007/ s11145-018-9893-y

12. Justice L, Koury A, Logan J. Ohio's Kindergarten Readiness Assessment: Does It Forecast ThirdGrade Reading Success?. [cited 2019 aug 10]. Available from https://earlychildhood.ehe. osu.edu/files/2019/05/Kindergarten-ReadinessWhitepaper_051619_SINGLES_WEB.pdf

13. Catts HW, Nielsen DC, Bridges MS, Liu YS, Bontempo DE. Early identification of reading disabilities within an RTI framework. J Learn Disabil. 2015;48(3):281-97. doi:10.1177/0022219413498115

14. OECD. Education policy outlook: Brazil. [cited 2019 aug 07]. Available from http://www.oecd.org/ education/Brazil-country-profile.pdf

15. Prova Brasil. [cited 2019 aug 07]. Available from http://portal.inep.gov.br/educacao-basica/saeb

16. Graham M, Milanowski A, Miller J. Measuring and promoting inter-rater agreement of teacher and principal performance ratings. Nashville: Center for Educator Compensation and Reform; 2012. Available from https://files.eric.ed.gov/fulltext/ ED532068.pdf

17. Melby-Lervåg $M$, Lyster SA, Hulme C. Phonological skills and their role in learning to read: a meta-analytic review. Psychol Bull. 2012;138(2):322-52. doi: 10.1037/a0026744

18. Engel de Abreu $P$, Tourinho $C$, Puglisi M, Nikaedo $\mathrm{C}$, Abreu N, Miranda M et al. A pobreza e a mente: perspectiva da ciência cognitiva. University of Luxembourg. 2015. Available from https://orbilu. uni.lu/bitstream/10993/20933/1/Engel de Abreu et al._Poverty and the Mind.pdf

19. Pedras CTPDA, Geraldo T, Crenitte PAP. Consciência fonológica em crianças de escola pública e particular. Revi Soc Bras Fonoaudiol. 2006;11(2):65-9.

20. Instituto Nacional de Estudos e Pesquisas Educacionais Anísio Teixeira. Censo da educação básica. 2018. Available from http://goo.gl/iQSIhp

21. Sales L. Escola ruim, aluno ruim. 2018. Available from http://tiny.cc/20mw8y

22. Schibli K, Wong K, Hedayati N, D'angiulli A. Attending, learning, and socioeconomic disadvantage: developmental cognitive and social neuroscience of resilience and vulnerability. Ann N Y Acad Sci. 2017;1396(1):19-38. doi:10.1111/ nyas.13369

23. Becskehazy I. Institucionalização do direito à educação de qualidade: o caso de sobral [tese]. São 
Paulo (SP): Universidade de São Paulo, Doutorado em Educação; 2018. doi:10.11606/T.48.2018. tde-04122018-175052

24. Wood T. Kindergarten Reading Readiness and Developmental Indicators for the Assessment of Learning. Walden Dissertations and Doctoral Studies. 2019. Available from https://scholarworks. waldenu.edu/dissertations/6706

\section{Erratum}

In the article, "Initial reading and writing skills in childhood education: achievement sample in the Northeast of Brazil for obtaining specific regional performance standards", with DOI number: $10.1590 / 1982-0216 / 201921513219$, published in the journal Revista Cefac 21(5):e13219, in the author's name and affiliation (page 1):

\section{Where it was:}

\section{Natália Dias Martins ${ }^{1}$}

1 Escribo Inovação para o Aprendizado, Recife, Pernambuco, Brasil.

\section{Read:}

\section{Natália Martins Dias ${ }^{2}$}

${ }^{2}$ Universidade Federal de Santa Catarina - UFSC, Florianópolis, SC, Brasil. 